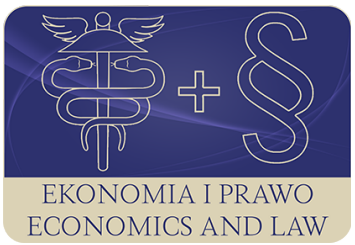

EKONOMIA I PRAWO. ECONOMICS AND LAW

Volume 19, Issue 1, March 2020

p-ISSN 1898-2255, e-ISSN 2392-1625

www.economicsandlaw.pl

EKONOMIA I PRAWO
ECONOMICS AND LAW

ORIGINAL ARTICLE

received 30.03.2019; revised 02.12.2019; accepted 31.03.2020

Citation: Stanowicka, A. (2020). The image of a city in selected theories of regional development.

Ekonomia i Prawo. Economics and Law, 19(1): 135-148. doi:10.12775/EiP.2020.010.

\title{
The image of a city in selected theories of regional development
}

\author{
AGNIESZKA STANOWICKA \\ University of Warmia and Mazury in Olsztyn, Faculty of Economic Science, Department \\ of Economics Theory, ul. Oczapowskiego 2, 10-900 Olsztyn, Poland \\ $\square$ agnieszka.stanowicka@uwm.edu.pl \\ (D) orcid.org/0000-0002-0004-8288
}

\begin{abstract}
Motivation: The image of the city is its non-physical resource which, if properly used, can become a factor in its development, attracting both capital and human resources of the city (e.g. tourists, investors, residents). According to the author, the municipality should create a model of the city's development, which will define its desired state the image which they will aim, stimulating its growth and development. In the construction of this model, and therefore the strategy of creating image of the city, it is advisable

to identify the factors that determine this development. On the basis of economics, the theories of regional development deal with the identification and assessment of development factors.

Aim: Image as a non-physical and internal resource of the city, is part of the scope of endogenous theories. The aim of the article is to review and evaluate these in terms of consideration the image of the city.

Results: Theories of regional development are not mutually exclusive, each theory introduces other development factors to the analysis, not excluding the most often assumptions and factors exposed in other theories. The assessment of the city's development potential (which results from the region's development) should not come from the adopted theory of regional development, but on the basis of known theories the factors creating cities image should be identify to improve his development.
\end{abstract}

Keywords: regional development; city development; image; identity

JEL: Rl1; R58; Oll; O43 


\section{Introduction}

The aim of this article is to relate selected regional and local development theories to the concept of creating a desirable image of a city. In order to achieve this goal, a review of relevant references and their critical analysis have been made in order to be able to apply well-known theories of regional development to diagnose determinants of a city's image and to identify distinguishing features of its identity. It was analyzed whether the chosen theories were in agreement with the principles of a strategy of building a city's image. The starting point was a review of definitions of regional development, local development and strategy of a city's identity. Next, theories of regional development which in the author's opinion could be valuable at the stage of designing a strategy of a city's identity were presented. Thus, rather than making a complete review of theories of development, the author suggests which theories deserve our attention at an early stage of building a strategy of a city's identity. The conclusions in the final part of this article, however, do not resolve the question which of the theories is the best in the above process, as each city is an individual case and it is impossible to create a universal model of building strategies for shaping an image of a city or town. Moreover, the conclusions are expected to serve as inspiration for further exploration of the topic analyzed below.

\section{Regional development versus image}

An image is considered to belong to a city's intangible assets, which by attracting investors, tourists, entrepreneurs and new inhabitants contributes to the city's development. The image is a marketable perception of identity, composed of the city's characteristic attributes which the city wishes to communicate to its environment. This communication is supported by the city's strategy, also known as the strategy of the city's identity. Determinants of a city's image have been investigated for several years now, and the overriding aim is to ensure that the development of a city's image is thoughtful, purposeful, ordered and subordinated to a uniform vision of the city's development. There is also ongoing search for ways of building a positive and distinct image of a city, an image that will clearly dominate over others, and that will eventually contribute to the economic growth of the city (as a factor which attracts both capital and human resources). The economic development is a concept often referred to areas larger than a city or town, for example to a region in which the cities lies. There are different definitions of the region, which is derived from the Latin word 'regio' which means - the area, zone, region, area, space, city, region, and district. The region (geographical meaning) is territorial entity with its own geographic structure which is framed in space and time, and that is difference from other units (Radulovic et al., 2015, p. 69). A region is also defined as a hierarchical system of central places or cities. Each region has a small number of large higher order cities and a large number of smaller, lower order cities (Dawkins, 2003, 
p. 134). A region is a homogeneous area with both physically and culturally distinct features, which distinguishes this region from the adjacent ones. Such features can include geographical (geographically uniform area), cultural (cultural identity of a given group), historical, administrative or economic characteristics. It is believed that the development of a city affects the development of the region in which it is situated, and vice versa, the regional development has influence on the development of cities it comprises.

The literature defines development is a process of structural transformations in a given society, stimulated by the economic growth, and it occurs in four domains: economic, political, social and cultural; the above processes are not uniform, although they mutually affect one another. It is understood as a social condition within a nation, in which the authentic needs of its population are satisfied by the rational and sustainable use of natural resources and systems. This utilization of natural resources is based on a technology, which respects the cultural features of the population of a given country (Reyes, 2001, p. 1). This is a process of positive changes, encompassing quantitative growth and qualitative development. These changes take place in a certain space and, according to its size, development is defined as local and regional. Regional development is a broader notion because it concerns a whole region. Local development is a process of changes occurring in a city, a rural commune, an urban-rural municipality, or in another subregion, delimited differently, i.e. in a social and territorial system which is distinguished by specific characteristics of the space, economy, culture and local preference of needs and hierarchy of values (Act on public procurement, 1994). Local development is an intricate process, which results in the creation of new values on the level of a city, for example, such as new companies, new jobs, new products and services, new locations, new infrastructural facilities, as well as new skills, qualifications and knowledge in the society. By creating new values, the society is able to achieve a better status, to become enriched and to assign a new sense of various activities. Development of a city entails a change, formation of other condition of the city, creation of its characteristics, often new ones. It is a long-term and complex process, orientated towards achievement of multidimensional outcomes, which simultaneously engages a variety of entities, social groups and institutions. For those connected with a given city, its development yields visible benefits (Duranton, 2015, p. 43):

- from the point of view of the residents, the quality of living in the city increases (the residents' incomes rise, new services appear which satisfy the above basic needs, the quality of infrastructure, roads and other urban subproducts improves);

- from the point of view of enterprises - the profitability of business enterprises increases owing to the growing market and higher revenues of the city population; 
- from the point of view of local authorities - their revenues increase, which creates a greater investment potential, providing a secondary boost to the city's development.

Development is therefore a phenomenon that is positive in all its aspects. And a major challenge for developing countries is to reinforce the role of their urban systems as drivers of economic growth.

\section{Methods}

The following hypothesis was proposed: a positive image of a city has a positive influence on the local development, which in turn has a positive influence on the regional development. It was observed that determinants of a city's image are most often a collection of the conditions underlying its development. When identified, they can therefore become the characteristic features of the city's identity, having then a planned and ordered impact on the desirable image of the city. Building a strategy of a city's identity is a process in which the following stages are distinguished:

- identification and evaluation of determinants of a city's identity;

- selection of target markets;

- determination of the objective of the strategy of the cities of identity (determination of a target image);

- selection of an array of tools (an identity mix);

- assignment of persons and units responsible for the accomplishment of the tasks;

- controlling.

The starting point in shaping a strategy of a city's identity is the identification and evaluation of determinants of the city's identity, and as noted before, these determinants arise from the conditions underlying the city's development and are a frequent subject raised in various theories of regional development. Thus, the purpose of this article is to undertake an effort and relate selected regional or local development theories to the concept of shaping a desirable image of a city. The author strives to resolve the questions: Which theories of development can serve as a foundation for building a strategy of identity? Which of these theories can be a starting point in planning a strategy of shaping a city's identity? Is there one, universal theory which could help the city authorities to recognize the conditions underlying a strategy of identity? The research method she applied consisted of a critical review of the literature.

\section{Selected theories of regional and local development versus strategies of a city's identity}

New regional industrial path development includes path renewal and path creation. Path renewal involves the growth of new activities and new industries 
via regional branching; existing knowledge and skills in a region are combined in new ways and may be linked to relevant, extra-regional knowledge to provide new knowledge for a region that enables innovations and entrepreneurship. Path creation represents the growth of entirely new industries for a region (Isaksen \& Jakobsen, 2017, p. 356). To evaluate the development of a city, its current state should be compared to what it was like in the past or to the condition of other cities (e.g. belonging to the same strategic group). This is the first problem which pertains to assessment of a city's development. Another problem is what measures to apply to make that assessment. There is no single, universal set of criteria that could serve the purpose. Development consists of much else besides economic growth and should be measured along other axes such as poverty, unemployment, inequality, and the strength of education and rights of citizenship (Pike et al., 2016, p. 6). The city authorities should create a certain model of the city - its desirable condition, an image which they will strive to attain, stimulating its growth and development. While building this model, i.e. the desirable image of the city, it is recommendable to identify the factors which are fundamental to this development. The identification and assessment of development factors are a task undertaken by theories of regional development, which can be divided into:

- theories based on external factors - exogenous theories ('bottom-up development');

- theories based on internal factors - endogenous theories ('top-down development').

Combined endogenous-exogenous model is advocated as the most convenient concept for developing (Kacar et al., 2016, p. 243). Image as an intangible asset of a city, by being the city's internal potential, inscribes itself into the scope of endogenous theories. In recent years, more attention has been paid to the activation of the endogenous potential of city and regions, including efficiency of public administration institutions, which should search for and make use of such possibilities. Endogenous theories presume that low mobility of production means, and therefore identify the following stimulants of regional development: new companies, new types of production, innovations, new jobs, and own resources. Resources may include a specific geographical location, quality of institutions, ethics, urban culture. Core ideas and elements are the understanding of development as a bottom-up process, a key role of local and regional actors and initiatives, including social agents and civil society, a high importance of decision-making functions, as well as of policy competences and institutions at local and regional levels (Tödtling, 201l, p. 340). Without doubt, all these factors create the core of a currant city's image. In the long term, however, the expected image should not be based on current resources, as these may change. One of the principal endogenous theories is the theory of basic needs, which rests on the assumption that a region (a city) develops uniformly based on own resources, focusing on satisfaction of social needs rather than on a rapid economic growth while. This theory relies on the principle that a region (a city) 
can satisfy needs of their residents by employing own resources, without external links. The economic and social development of a city should proceed at a rate typical of this city, and not in a rush to catch up with the rate of most of other cities (often using alternative strategies of development, which will be characteristic only for a given city). This is an idea strongly connected with the guidelines of the strategy of identity, which should be individual, unique and typical of a given city only, based on distinguishing, specific attributes, and shaping a unique image of this city. The tasks that this theory envisages for all administrative authorities involve strengthening the specialization trend, investing in infrastructure (telecommunication, transport), supporting financial and consulting institutions, and providing services for business and education (Szajnowska-Wysocka, 2009, p. 77). An interesting example of a concept of development based on the theory of basic needs is the development designed in line with the philosophy of slow city. The fundamental notions of this theory are to offer city inhabitant a new, higher quality of life arising from a slower rhythm of living in a slow city. Cittaslow is a kind of ecological and humanistic movement which protects the local and traditional culture and supports to continue the comfort and enjoyment in life (Tranter, 2010, p. 240). Cities which adhere to the concept of slow life develop through improvement of the quality of life of their dwellers, enhancement of the city's appeal and consequently its greater competitiveness. Currently, many cities, especially small ones, undertake efforts to build their image according to the concept of slow city.

Another important theory of regional development is the theory of network development, based on increased social capital and cooperation within a region, where this collaboration can strengthen activities that create an image of individual network units (cities). A network of cities is a structure where the nodes are the cities, connected by links of different nature, through which flows of socioeconomic nature are exchanged (Boix, 2003, p. 33). Network of cooperation is a specific type of relationships, bringing together people, objects, events (in our case, cities) in order to gain mutual benefits. Among possible gains there is a lasting, positive image of city involved in a network of cooperation, which can produce a feedback effect on their economic and social development. Cooperation enables the networked entities to exchange information, ideas, and to create an atmosphere of trust and economic collaboration. The issue of cooperation is also mentioned in Alfred Marshall's theory, in which he described so-called industrial districts, which were first established in Italy and which consisted of networks of small, mutually cooperating, family-owned companies. On the basis of such experiences, it is suggested that other subjects, including public institutions, also spread over larger geographical areas, can engage in cooperation. According to Marshall's concept, a network cooperates with all networked partners to solve problems, look for innovative solutions, organize marketing campaigns and training sessions together, and to run a promotional campaign for the sake of creating an image of the networked and associated entities. As an example of a network of cooperation of cities, let us 
again recall cities which are developed in line with the philosophy of slow city, and which are associated in the Cittaslow network. The Cittaslow movement was started in 1999 in Italy, and since then it has been joined by over 240 cities from all the world. The network associates small cities whose authorities consider the concept of slow life as an opportunity to improve the quality of life of their residents, by taking advantage of the fact that these are good, peaceful localities, from globalized 'rushing' cities, and emphasizing it as a distinct feature of identity. Cittaslow is preferred because of the different aims such as; being included in Cittaslow International Network, improving the quality of urban life, sustaining the on going regional development, protecting urban self-identity, creating the awareness being related with the urban differences, providing the urban transformation, increasing the power of competition in extention of international, avoiding the disadvantages of globalization, developing the social relations, increasing the being well known in international area, increasing the touristic appeal and using it of the brand destination (Tayfun, 2014, p. 158).

Another theory that underlines the role of cooperation of subjects in local and regional development is the theory of innovative regional environment, which maintains that innovations are a source of development, both on a local and regional level, and innovations require cooperation on three planes, defined as commercial enterprises, research and development institutions, and local authorities (Sventas, 2014, p. 24). Innovations and an innovative environment create a specific image of a city, i.e. a modern city, orientated towards development, with good future prospects, and these attributes will usually draw more attention to this city in the future.

A special feature that distinguishes the identity of any city is its social capital, which has been characterized as a set of relationships between people in a given community. The theory of human capital also rests on a network of cooperation between research, and economic institutions, think tanks, and regional as well as central administration. This theory defines social capital as a profitable resource based on the existence of some kind of relations and/or social norms, namely, as a collective, indivisible resource, and as a public good (Boccella \& Salerno, 2016, p. 293). This resource constitutes a significant distinguishing feature of the identity of a city or region by shaping its image.

Another concept lays the foundation of the theory of clusters, which envisages clusters of business companies and institutions that simultaneously cooperate and compete with one another, and this entails an increase in productivity and innovation, while decreasing costs of production. The concept was developed by Porter (1990), who argued that in the modern global market, competition is implemented not by means of separate economic subjects, but with the help of groups of economic subjects (clusters) (Sventas, 2014, p. 21). He treated industrial clusters as a tool to investigate the competitive advantage in contemporary global economy. Cooperating entities exchange information, take advantage of human resources available in the region, create a network 
of cooperation, which is also a network of competition (Szajnowska-Wysocka, 2009 , p. 81). This is referred to as coopetition, an idea which may become an element of the strategy of identity implemented by cities.

R. Florida introduced into the literature the notion of 'a learning region'. The theory of learning regions underlines the role of innovation and technology in stimulating regional development, and the resource which needs to be developed consists of knowledge and skills. This concept can be rightly related to the question of building a city's image, where the shaping of an image is based on knowledge and its effects such as new technologies and innovative solutions, which should encourage local development. Development based on knowledge surpasses capacities of single companies, and therefore the knowledge resources ought to be expanded up to the scale of an entire region. The key mechanisms of collective learning have been identified: the mobility of qualified labor, knowledge exchange through informal networks and the setting up of spin-off businesses (Morgan, 1997, p. 26). It is proposed to include local or regional authorities in the creation of a system of innovations in a city (or region), i.e. public institutions which act together for the sake of technological development, which support the network of cooperation between science and research institutes, think tanks and companies, stimulate research carried out by companies, support research institutions collaborating with industry, provide funds to conduct high risk and long-term research, etc. The image of a city developed in compliance with the theory of learning regions is that of a university city, where research institutions collaborate with business (a network of cooperating institutions), and where there is an atmosphere of trust and cooperation, local entrepreneurship traditions are sustained, and this in turn leads to the development of innovations and new forms of.

Among more recent notions of regional development, there is the theory of smart specialization, which was coined by D. Foray. This theory also relies on knowledge as a determinant of regional development, but suggests that the latter can be accelerated owing to stronger R\&D potential in the region. The proponents of this theory also underline the important role of cooperation between entities operating in the region, which can learn from one another. Cooperation pertains to business companies, higher education institutions, R\&D institutions, administration and non-government organizations. The policy makers need assistance from academic community in order to fully understand the content and the application options, to design and apply effective and relevant smart tools for the assessment and measurement of the smart potential of a region, of the real opportunities to support new competitive areas, and to integrate these new opportunities into the existent Sectorial structure (Sandu, 2012, p. 237).

Another endogenous theory which can be associated with the strategy of identity, creating a positive image of a city, is the institutional theory. This theory stresses the necessity to create law which will support the spirit of enterprise, protect property rights, and shape the economic culture. The theory 
investigates the role of institutions in economy, covering such issues as the importance of institutions in the development of economy, their connection with the flows of goods and capital, and institutional change. It has been demonstrated that certain institutional solutions stimulate the development of regions (and consequently, cities), by facilitating the creation of knowledge, innovations and new technologies. The institutional approach was referred to by $\mathrm{M}$. Stroper (1997, pp. 5-52), who in addition to the above pointed to the role played in regional or local development by so-called non-trade relations between economic entities, e.g. formal and informal rules of social life, habitual behaviours and customs which influence the actions undertaken by subjects of regional economy. These relations encourage an increase in initiatives and entrepreneurship, stimulated by cooperation. This has a beneficial influence on the image of cities and regions, and therefore should be considered when building a strategy of a city's image.

The literature also mentions theories which suggest that it is possible to shape a unique image of a city weakly connected with its environs. Such as the theory of independent development, which particularly applies to peripheral regions and city within such regions, and which claims that subjects should concentrate on reinforcing their own, endogenous potential, exposing and developing own resources and assets (possibly using technologies and innovations from the external resources). Other theories of development which implicate weak connections with the environment or complete disconnection from the external surroundings (e.g. theory of autocentric development), theoretically could play some role in strategies of the identity of cities in the context of the uniqueness of a city's image, but in the era of globalization and the resulting demand for cooperation, such theories are unlikely to succeed and be included in identity strategies developed by cities.

It is worth mentioning that theories of regional and local development can be grouped into ones based on neoclassical economics and Keynesian theories. The former envisage absence of interference of local authorities in reducing disparities between regions in terms of development. Such theories maintain that in the long run market mechanisms themselves will lead to the levelling of development in different regions. Neoclassical growth models focus on the accumulation of physical, human, and technological capital, which individually or together complement raw labor and land as factors of production (Sachs \& McCord, 2008, p. 1). The group of theories arising from the school of economics developed by J.M. Keynes presume that authorities actively participate in economic processes in order to improve the functioning of markets and to eliminate excessive differences in the level of regional development. With respect to the shaping of a city's image, the role of local authorities in the implementation of the strategy of the city's identity is emphasized, and the expected outcome is a positive image of the city in its environment, both internal and external one. Cooperation between the local community and city's authorities is desirable, as it leads to better mutual understanding between these two groups, as a re- 
sult of which city residents understand and accept actions undertaken by local authorities, while city authorities begin to act in a market-orientated manner, i.e. through the prism of needs of their customers. Such cooperation can lead to the development of a city in a desirable, socially acceptable direction. Considering the strategy of identity implemented in cities, the Keynesian approach seems more appropriate. The strategy of identity as a plan of building a desirable image of a city is created by the local authorities (possibly with the participation of city inhabitants and other subjects), and is then implemented and coordinated by the same authorities. It is the city's authorities that are responsible for how successful the strategy is, and the strategy needs to be verified periodically so as to achieve desirable changes in the city's image.

Other theories of development touch on the problem of infrastructure and its impact on the development of regions and regional towns. Many authors claim that there is a strong relation between the growth in infrastructure and potential opportunities for regions or cities to develop. Infrastructure is one of the strongest components of a city's image and obviously the question of the shape and growth of infrastructure needs to be included in the strategy of a city's image.

Finally, it is worth noting that increasingly more attention has been paid recently to issues of environmental conservation and ecology. Environmental factors, to a large extent, contribute to the image of a city in its environs. The most popular theory of regional development that emphasizes the role of environmental attributes is the theory of sustainable development. Sustainable development has become the dominant concept in the study of interactions between the economy and the biophysical environment, as well as a generally accepted goal of environmental policy (Mulder, \& van den Bergh, 2001, pp. 110-134). This is concept of conserving resources for future generations, this is one of the major features that distinguish sustainable development policy from traditional environmental policy, which also seeks to internalize the externalities of environmental degradation. The overall goal of sustainable development is the long-term stability of the economy and environment; this is only achievable through the integration and acknowledgement of economic, environmental, and social concerns throughout the decision making process (Emas, 2015, p. 2). Sustainability (sustainable development) means positive changes in respect to the future of an association to guarantee its long-term survival (strengthening) (Reiljan, 2014, p. 125)

Among the equilibria in these domains, two additional conditions underlying the economic development are mentioned, such as spatial order and institutional order. It is noteworthy that attainment of sustainable development is not an aim limited to a single city, region or state, but is a global pursuit. It concerns equally all cities in the world, which should join in its achievement. For cities, the most difficult type of equilibrium is ecological balance, because urban growth entails intensive exploitation of the natural environment, not only within the city's limits but also on its outskirts. But regional and local devel- 
opment is considered as one of the possible ways to overcome the economic and environmental crisis. Some authors call its eco-development, as philosophy of development (Urteaga, 2011, p. 399), which should aim to reduce the spatial expansion of towns and cities and simultaneously, to take great care of the quality of life of city dwellers. Nowadays smart growth and smart cities are especially popular. They are characterized by the pervasive use of Information and Communication Technologies (ICT), which, in various urban domains, help cities make better use of their resources. Many smart cities are thus sophisticated systems that 'sense and act', and in which a great volume of real-time information is processed and integrated across multiple processes, systems, organizations and value chains to optimise operations and inform authorities on incipient problems. Smart initiatives do not only entail technology changes, but also investments in human capital and changes in urban living practices and conditions. In other words, ICT is a General Purpose Technology (Bresnahan \& Trajtenberg, 1995), which is complementary to human and organizational capital and whose usage is shaped by political choices and by the urban ecosystem of the citizens, technology vendors and local authorities, depending on the city $\mathrm{s}$ needs and habits (Neirotti et al., 2014, pp. 6-8).

The theory of sustainable development comprises an assumption that in the long term a distinct image of a city (or region) will be created, which is consistent with the principles of the identity strategy (the image of a city is a resource that can not be generated in a short time). The idea of a long-lasting life of an image of space, once it is achieved, is particularly strongly expressed in the theory of sustainable development, which requires a balanced and integrated analysis from three main points of view: economic, social and environmental. Each viewpoint represents a domain and a system that has its own distinct driving forces and objectives (Rogers et al., 2008, p. 12). This broad approach is sometimes called the theory of integrated development. Worth-living integrated development satisfies the need for the comprehensive dialectical harmony, symmetry and balance in the process of completion of development with the 'economic', 'social', 'political' and 'cultural' dimensions. This development is in harmony with nature and traditions, but also with the progress of science and technology (Koroneos \& Rokos, 2012, p. 146).

\section{Conclusion}

In conclusion, it can be noted that numerous theories of regional and local development are not mutually exclusive, although none of them provides a definite answer as to what stimulates and what retards economic growth or, in other words, what has the strongest influence on the image of a city and what local authorities should focus on mostly when implementing the strategy of a city's identity. The theories are also difficult to classify. Each theory introduces different development factors into analysis, although none excludes the factors or conditions emphasized in other theories. Consequently, an assessment 
of a city's development potential (which arises from the development of the region) should not originate from the adopted theory of regional development; conversely, based on known theories, factors characteristic for a given city should be identified, as they can shape a distinct image of the city and determine its development.

The image of a city, which is its intangible, internal asset, can be inscribed in the scope of endogenous theories. These theories put stress on the development of one's own potential. Many underline the need 'to slow down' the rate of development, and to develop a city at its own, individual pace. This is proposed in the theory of basic needs, and some city authories follow this approach, for example by joining the Cittaslow network, where they make attempts to implement the concept of developing a slow city. This direction in city development also manifests the role of cooperation and collaboration in contemporary cities. The Cittaslow network is a network of cooperation of small towns, where the pace of development will never be as rapid as in large agglomerations. The need of cooperation is also mentioned in the theory of social capital, Marshall's theory, theory of clusters and the theory of network development. Owing to cooperation, the image of cities can be more expressive, thus making pro-development measures more effective. Few cities or towns can focus on building their image by separating themselves from the environment and relying solely on the assumptions of development, as expressed in the theory of independent development. This assumption could work only for cities that possess truly significant distinguishing characteristics. Most contemporary cities rely their development on cooperation with others, and not on being separated from the surroundings.

A significant distinguishing feature of the identity of contemporary cities which may contribute to their development is knowledge, which arises from scientific research and high level of education in a given city. Knowledge encourages innovations, thus stimulating the economic growth of the city and region. This aspect is raised, for instance, in the theory of regional innovative environment, theory of social capital or the theory of smart specialization. Other theories of regional development underline that the creation of knowledge, innovations and new technologies can facilitate certain solutions (the theory of institutionalism). Local authorities should be engaged in the stimulation of the city's development, and are also responsible for planning and implementing their strategy of shaping the city's image. For this reason, neoclassical theories rather than Keynesian ones are more appropriate. The most popular theory in the recent years has been the theory of sustainable development. It puts emphasis on most elements which in the earlier theories have been treated only fragmentarily. The theory of sustainable development, by being a complex approach, stresses the aspects that can become a source of the competitive advantage of a city. The image of a city which will be shaped could stem from a more than average growth of the local economy, distinctly delineated social order, both providing the residents with high quality of life, from environmental assets, or from 
all these factors simultaneously. In addition, the theory of sustainable development is a long-term approach, which is in line with the assumptions underlying the formation of a city's image. It is therefore a good starting point in planning a strategy of identity, as it points to priority areas for the city's development, on which the city's image can focus.

\section{References}

Boccella, N., \& Salerno I. (2016). Creative economy, cultural industries and local development. Procedia: Social and Behavioral Sciences, 223. doi:10.1016/j. sbspro.2016.05.370.

Boix, R. (2003). Networks of cities and growth: theory, network identification and measurement of the network externality. European Business Module Universita di Firenze, 13/14.

Bresnahan, T.F., \& Trajtenberg, M. (1995). General purpose technologies: engines of growth? Journal of Econometrics, 65(1). doi:10.1016/0304-4076(94)01598-t.

Dawkins, C.J. (2003). Regional development theory: conceptual foundations, classic works, and recent developments. Journal of Planning Literature, 18(2). doi:10.1177/0885412203254706.

Duranton, G. (2015). Growing through cities in developing countries. The World Bank Research Observer, 30(1). doi:10.1093/wbro/lku006.

Emas, R. (2015). The concept of sustainable development: definition and defining principles. Brief for GSDR.

Isaksen, A., \& Jakobsen, S. (2017). New path development between innovation systems and individual actors. European Planning Studies, 25(3). doi:10.1080 /09654313.2016.1268570.

Kacar, B., Curic, J., \& Ikic S. (2016). Local economic development in theories of regional economies and rural studies. Economics of Agriculture, 63(1). doi:10.5937/ekopolj1601231k.

Koroneos, C.J., \& Rokos, D. (2012). Sustainable and integrated development: a critical analysis. Sustainbility, 4(1). doi:10.3390/su4010141.

Morgan, K. (1997). The learning region: institutions, innovation and regional renewal. Regional Studies, 31(5). doi:10.1080/00343409750132289.

Mulder, P., \& van den Bergh, J. (2001). Evolutionary economic theories of sustainable development. Growth and Change, 32(1). doi:10.1111/0017-4815.00152.

Neirotti, P., De Marco, A., Cagliano, A.C., Mangano, G, \& Scorrano, F. (2014). Current trends in smart city initiatives: some stylised facts. Cities, 38. doi:10.1016/j.cities.2013.12.010.

Pike, A., Rodríguez-Pose, A., \& Tomaney, J. (2016). Shifting horizons in local and regional development. Regional Studies, 51(1). doi:10.1080/00343404.2 016.1158802.

Porter, M.E. (1990). The competitive advantage of nations. New York: Free Press. 
Radulovic, D., Pindzo, R., Radulovic S., \& Vukovic, D. (2015). Region as a basic territorial unit of regional development. Economic Analysis, 48(3-4).

Reiljan, J. (2014). Regional development sustainability analysis concept. Discussions on Estonian Economic Policy: EU Member States After the Economic Crisis, 1. doi:10.2139/ssrn.2493019.

Reyes, G.E. (2001). Four main theories of development: modernization, dependency, word-system, and globalization. Nómadas. Critical Journal of Social and Juridical Sciences, 4(2).

Rogers, P., Jalal, K., \& Boyd, J. (2008). Preface. In P. Rogers, K. Jalal, \& J. Boyd (Eds.), An Introduction to Sustainable Development. London: Eartscan.

Sachs, J.D., \& McCord, G. (2008). Geography of regional development. In S.N. Durlauf, \& L.E. Blume (Eds.), The new Palgrave dictionary of economics. London: Palgrave Macmillan.

Sandu, S. (2012). Smart specialization concept and the status of its implementation in Romania. Procedia Economics and Finance, 3. doi:10.1016/ s2212-5671(12)00146-3.

Stroper, M. (1997). The regional word: territorial development in a global economy. New York: The Guilford Press.

Sventas, K.Z. (2014). Strategic planning for regional development: an introductory textbook. Vilnius: Mykolas Romeris University.

Szajnowska-Wysocka, A. (2009). Theories of regional and local development: abridged review. Bulletin of Geography. Socio-economic series. 12(12). doi:10.2478/v10089-009-0005-2.

Tayfun, A. (2014). Cittaslow: a comparative research Turkey and the world. Conference of the International Journal of Arts \& Sciences, 7(3).

Tödtling, F. (2011). Endogenous approaches to local and regional development policy. In A. Pike, A. Rodriquez-Poze, \& J. Tomaney (Eds.). Handbook of local and regional development. New York: Routledge.

Tranter, P.J. (2010). Speed kills: the complex links between transport, lack of time and urban health. Journal of Urban Health, 87(2). doi:10.1007/ sl1524-009-9433-9.

Urteaga, E. (2011). The alternative theories of sustainable development. Boletín de la Asociación de Geógrafos Espandes, 52.

Ustawa z dnia 10 czerwca $1994 \mathrm{r}$. o zamówieniach publicznych [Act of 10 June 1994 on public procurement] (Dz.U. 1994 nr 76 poz. 344) (Poland).

\section{Acknowledgements}

Author contributions: author has given an approval to the final version of the article.

Funding: this research was funded by the University of Warmia and Mazury in Olsztyn, Faculty of Economic Science sources.

Note: the results of this study were presented at 10th International Conference on Applied Economics Contemporary Issues in Economy (June 27-28, 2019, Torun, Poland). 